\title{
Low Vitamin D as A Risk Factor for Gestational Diabetes in Egyptian Pregnant Women
}

\author{
Gehan Abdelkader Ibrahim ${ }^{1}$, Ihab Mohammed Ahmed Salem ${ }^{1}$, Hoda Goda Bakr', \\ Amina Mohammed Talaat Al Naggar ${ }^{2}$, Rasha Elsayed Hussien Omar ${ }^{1}$ \\ ${ }^{1}$ Department of Internal Medicine, ${ }^{2}$ Department of Clinical Pathology, Faculty of Medicine, Zagazig University
}

\begin{abstract}
Background: Gestational diabetes mellitus (GDM) is a worldwide problem affecting about $16.5 \%$ of pregnancies all over the world, with serious maternal and fetal complications. Vitamin D (Vit D) deficiency during gestation is widespread and during the last 10 years. A lot of studies found an association between decreased Vit D and impaired glycaemia concluding that deficient Vit D might be a modifiable risk factor for GDM. Objective: The aim was to detect whether maternal Vit D insufficiency during pregnancy is a risk factor for GDM.

Materials and Methods: Case-control study done in Outpatient Clinics at Zagazig University Hospitals to assess relation between GDM and low Vit D. 96 pregnant women were studied, 48 had GDM (diagnosed by OGTT according to ADA criteria) and the other 48 had normal pregnancy. 25-Hydroxyvitamin D (S.25 OHD) was measured.
\end{abstract}

Results: Increased prevalence (68.75\%) of Vit D insufficiency was found in both groups. S.25 (OH) D was significantly lower in ladies with GDM in comparison with controls $(26.8 \pm 32.2 \mathrm{ng} / \mathrm{ml}$ vs $42.6 \pm 4.2 \mathrm{ng} / \mathrm{ml})$. Fasting blood sugar in early gestation has insignificant negative correlation with $25(\mathrm{OH}) \mathrm{D}$ level $(\mathrm{r}=-0.06)$ Conclusion: There is statistically significant difference between case and control groups in $25(\mathrm{OH})$ VIT D level with higher occurrence of Vit D deficiency/insufficiency in the GDM group

Keywords: GDM, S. 25 (OH) D concentrations, Vit D deficiency, Insulin resistance.

\section{INTRODUCTION}

Gestation is normally accompanied by insulin resistance like that occurs in type 2 diabetes (T2DM). This physiological resistance to insulin function in gestation becomes more evident in the $2^{\text {nd }}$ trimester, and insulin resistance progressively increases till delivery. If this maternal resistance to insulin becomes more pronounced, maternal hyperglycemia exists and GDM might be diagnosed ${ }^{(\mathbf{1})}$. GDM is defined as any degree of glucose intolerance leading to a state of hyperglycemia of variable severity, first found in pregnancy, whatever the needed treatment or postpartum evolution of diabetes or not ${ }^{(2)}$.

GDM almost complicates $4 \%$ of all pregnancies and females with GDM have an estimated 7-fold risk of occurrence of future T2DM, as well as their children and subsequent generations The total prevalence of GDM has been approximately supposed to reach $15 \%-20 \%{ }^{(3)}$. Screening of GDM is advised at $24-28^{\text {th }}$ weeks of gestation in pregnant females who were not previously diagnosed as having overt diabetes either by 1 or 2 step method of diagnosis ${ }^{(4)}$.

Risk factors for GDM include increased parity, high maternal age, pre-gestation obesity, family history of DM and obstetric history of GDM, delivery of a macrosomic infant, or infant with congenital malformation, but is not obvious whether a decreased Vit D level is associated with the risk of GDM ${ }^{(5)}$.
Vit D whatever synthesized de novo in the skin from cholesterol (cholecalciferol) or taken orally from the diet as a precursor (cholecalciferol and ergocalciferol), is hydroxylated to 25hydroxyvitamin $\mathrm{D}(25(\mathrm{OH}) \mathrm{D})$ in the liver. Assessing the circulating serum level of $25(\mathrm{OH}) \mathrm{D}$ is accepted to be the most reliable detector of one's Vit D status. Then, 25( $\mathrm{OH}) \mathrm{D}$ undergoes another renal hydroxylation to the active 1, 25dihydroxyvitamin $\mathrm{D}(1,25(\mathrm{OH}) 2 \mathrm{D})$ under control by parathyroid hormone $(\mathrm{PTH})^{(6)}$.

Vit $\mathrm{D}$ deficiency is a common problem nowadays, due to living indoors and sunscreens use (7). Vit D plays a vital role in the regulation of bone metabolism and has a great effect on muscle strength and effects on cellular differentiation, proliferation, immune regulation, apoptosis, neurogenesis and genome stability. New studies have also supposed that Vit D is closely associated with cardiovascular diseases, diabetes, cancers, autoimmune diseases, infectious diseases and others ${ }^{(8)}$.

Vitamin D regulates glucose metabolism by influencing insulin sensitivity, though the definite mechanisms are still not completely understood. The pancreatic $\beta$ cells express both Vit D receptor and enzyme $1 \alpha$-hydroxylase that allows them to produce $1,25(\mathrm{OH}) 2 \mathrm{D}$ locally ${ }^{(9)}$.

Vit $D$ deficiency might also increase systemic inflammation which also has a vital role in T2DM pathogenesis ${ }^{(\mathbf{1 0})}$. 


\section{SUBJECTS AND METHODS}

Study design:

Hospital-based case-control study during pregnancy. Case and controls were recruited from Outpatient Clinics at Zagazig University Hospitals Case definition: Pregnant women who had GDM in the age group 18-40 years old with $F P G \geq 92$ $\mathrm{mg} / \mathrm{dl}$ and $2 \mathrm{~h}$ after $75 \mathrm{gm}$ glucose $\geq 153 \mathrm{mg} / \mathrm{dl}$.

\section{Control definition:}

Normal FPG $<92 \mathrm{mg} / \mathrm{dl}$.

To avoid the effect of seasonal variation on Vit D levels, the execution of study subjects was applied on females whose $24-30^{\text {th }}$ weeks of pregnancy (i.e., the first, mid-gestational blood sampling) in winter months (i.e., December, January and February).

\section{Inclusion criteria:}

GDM or non-GDM pregnancy: using OGTT with $75 \mathrm{gm}$ of glucose applied between $24^{\text {th }}$ and $30^{\text {th }}$ weeks of gestation. GDM diagnosis was determined according to the ADA 2019 criteria: FPG $\geq 92 \mathrm{mg} / \mathrm{dl}, 1 \mathrm{hr}$. after load glucose $\geq 180$ $\mathrm{mg} / \mathrm{dl}$ and $2 \mathrm{hr}$. post glucose load $\geq 153 \mathrm{mg} / \mathrm{dl}$ (any one of the 3 above cut-off values accepted for the GDM diagnosis).

\section{Exclusion criteria:}

Diabetes mellitus type 1 or 2 before pregnancy, severe comorbidities (cancer, lupus, hepatitis, and renal diseases), thyroid or parathyroid illness mal-absorption syndrome (clinically) and those taking anticonvulsant drugs, calcium or vitamin D therapy or underwent gastric bypass surgery.

All subjects were instructed to fast 8 hours. A blood sample of $6 \mathrm{CC}$ was withdrawn from fasting subjects on sterile plain vacutainer and the sample was allowed to clot and sera were separated for analysis of fasting blood sugar, S. calcium, phosphorus, Creatinine, AST, ALT , albumin, and 25(OH)VIT D). OGTT was done for confirmation or exclusion of GDM. Plasma was separated by centrifugation $10 \mathrm{~min}, 4^{\circ} \mathrm{C}$ and stored at $-70^{\circ} \mathrm{C}$ until analysis. $25(\mathrm{OH}) \mathrm{D}$ was assessed by in vitro diagnostic enzyme.

\section{Ethical Consideration:}

Study Approved from the Ethical Review Committee at Zagazig University was obtained prior to the study (10/2017). Written informed consent was obtained from all study participants after the explanation of the study objectives and nature and assuring that confidentiality will be maintained throughout the work.

\section{Data Management and Analysis:}

The data were collected, revised, verified and statistically analyzed by SPSS version 23 . Descriptive statistics were conducted to describe the sample population. Qualitative data were presented in number and percent. Quantitative variables were described as mean \pm SD. Association between categorical variables was tested by Chi-square test. The two groups were compared with Student's t test (parametric data). Analysis Of Variance (ANOVA) test was used for comparing means of more than 2 groups. Correlation between various variables was detected by Pearson's correlation co-efficient (r) for parametric data. Level significance for all previously mentioned statistical tests done, the threshold of significance is fixed at 5\% level (pvalue $<0.05$ ).

\section{RESULTS}

Characteristics of study subjects in both groups are presented in table (1) and there was no statistically significant difference between the case and control groups regarding age, BMI and residence.

Table (1): Comparison between socio-demographic characteristics and BMI of the case and control groups

\begin{tabular}{|c|c|c|c|c|c|}
\hline Variable & $\begin{array}{c}\text { Case }(48) \\
\text { mean } \pm \text { SD } \\
(\text { Range }) \\
\text { median }\end{array}$ & $\begin{array}{c}\text { Control (48) } \\
\text { mean } \pm \text { SD } \\
(\text { Range) } \\
\text { median }\end{array}$ & Test & & p-value \\
\hline Age & $\begin{array}{c}28.3 \pm 5.1 \\
(20-40) \\
27\end{array}$ & $\begin{array}{c}26.9 \pm 5.1 \\
(18-39) \\
26\end{array}$ & 1.3 & & 0.18 \\
\hline$B M I$ & $\begin{array}{c}26.8 \pm 3.9 \\
(20-40) \\
26\end{array}$ & $\begin{array}{c}25.8 \pm 4.2 \\
(19-40) \\
25\end{array}$ & 1.2 & & 0.2 \\
\hline Variable & $\begin{array}{c}\text { Case } \\
\text { No(48) } \% \\
\end{array}$ & $\begin{array}{c}\text { Control } \\
\text { No(48) } \% \\
\end{array}$ & $\chi^{2}$ & $\begin{array}{c}\text { p- } \\
\text { value }\end{array}$ & $\begin{array}{c}\text { Odds } \\
\text { (CI 95\%) } \\
\end{array}$ \\
\hline $\begin{array}{l}\text { Residence } \\
\text { Rural (50) } \\
\text { Urban (46) }\end{array}$ & $\begin{array}{ll}21 & 43.8 \% \\
27 & 56.3 \%\end{array}$ & $\begin{array}{l}60.4 \% \\
39.6 \%\end{array}$ & 2.6 & 0.1 & $\begin{array}{c}1.9 \\
(0.8-4.4)\end{array}$ \\
\hline
\end{tabular}


Table (2): Comparison between calcium, 25(OH) VIT D and sun exposure in the case and control groups

\begin{tabular}{|c|c|c|c|c|c|}
\hline Variable & $\begin{array}{l}\text { Case }(48) \\
\text { mean } \pm \text { SD } \\
\text { (Range) } \\
\text { median }\end{array}$ & $\begin{array}{l}\text { Control (48) } \\
\text { mean } \pm \text { SD } \\
\text { (Range) } \\
\text { median }\end{array}$ & Test & \multicolumn{2}{|c|}{ p-value } \\
\hline $\operatorname{Calcium}(m g / d l)$ & $\begin{array}{l}8.4 \pm 0.8 \\
(7-11) \\
8\end{array}$ & $\begin{array}{l}9.4 \pm 0.6 \\
(7.9-11) \\
9.5\end{array}$ & 6.8 & \multicolumn{2}{|c|}{$0.001 * *$} \\
\hline $25(\mathrm{OH})$ VIT $D(\mathrm{ng} / \mathrm{ml})$ & $\begin{array}{l}26.8 \pm 32.2 \\
(0.5-205) \\
21\end{array}$ & $\begin{array}{l}42.6 \pm 4.2 \\
(11-212) \\
24.5\end{array}$ & $\begin{array}{l}\text { M.W } \\
2.4\end{array}$ & \multicolumn{2}{|l|}{ 0.03* } \\
\hline Variable & $\begin{array}{l}\text { Case } \\
\text { No(48) } \%\end{array}$ & $\begin{array}{l}\text { Control } \\
\text { No(48) \% }\end{array}$ & $\chi^{2}$ & $\begin{array}{l}\text { p- } \\
\text { value }\end{array}$ & $\begin{array}{l}\text { Odds } \\
\text { (CI 95\%) }\end{array}$ \\
\hline $\begin{array}{l}\text { Sun exposure } \\
\text { low (63) } \\
\text { high (33) }\end{array}$ & $\begin{array}{cc}35 & 72.9 \% \\
13 & 27.1 \%\end{array}$ & $\begin{array}{l}57.3 \% \\
41.7 \%\end{array}$ & 2.3 & 0.1 & $\begin{array}{l}0.5 \\
(0.2-1.2)\end{array}$ \\
\hline
\end{tabular}

In this table, there was statistically significant difference between the case and control groups in 25(OH) VIT D and s. calcium with higher levels in control group. Regarding sun exposure, there was no statistically significant difference between the 2 groups.

Table (3): Comparison between maternal weight gain during pregnancy and neonatal birth weight in the case and control groups

\begin{tabular}{|l|c|c|c|c|}
\hline \multicolumn{1}{|c|}{ Variable } & $\begin{array}{c}\text { Case (48) } \\
\text { mean } \pm \text { SD } \\
\text { (Range) } \\
\text { median }\end{array}$ & $\begin{array}{c}\text { Control (48) } \\
\text { mean } \pm \text { SD } \\
\text { (Range) } \\
\text { median }\end{array}$ & Test & p-value \\
\hline $\begin{array}{l}\text { Maternal weight } \\
\text { gain(kg) }\end{array}$ & $\begin{array}{c}10.9 \pm 1.5 \\
(8-14)\end{array}$ & $\begin{array}{c}8.5 \pm 1.2 \\
(7-12) \\
8\end{array}$ & 8.6 & $\mathbf{0 . 0 0 1 * *}$ \\
\hline $\begin{array}{l}\text { Neonatal birth } \\
\text { weight(kg) }\end{array}$ & $\begin{array}{c}\text { (1) } \\
(2.8 \pm 0.5\end{array}$ & $\begin{array}{c}2.8 \pm 0.2 \\
(2.2-3.3) \\
3\end{array}$ & 12.1 & $\mathbf{0 . 0 0 1 * *}$ \\
\hline
\end{tabular}

** Statistically highly significant difference $(\mathrm{P} \leq 0.001)$.

In this table, there was statistically significant higher neonatal birth weight and maternal weight gain in the case than the control group.

Table (4): Comparison between case and control groups regarding fasting \& post-prandial blood glucose levels in the $2^{\text {nd }}$ trimester and family history of D.M.

\begin{tabular}{|c|c|c|c|c|c|}
\hline Variable & $\begin{array}{c}\text { Case }(48) \\
\text { mean } \pm \text { SD } \\
\text { (Range) } \\
\text { median } \\
\end{array}$ & $\begin{array}{c}\text { Control (48) } \\
\text { mean } \pm \text { SD } \\
(\text { Range }) \\
\text { median } \\
\end{array}$ & Test & \multicolumn{2}{|c|}{ p-value } \\
\hline $\begin{array}{ll}\begin{array}{l}\text { Fasting } \\
\text { glucose }(\mathrm{mg} / \mathrm{dl})\end{array} & \text { blood }\end{array}$ & $\begin{array}{c}110.8 \pm 14.9 \\
(72-166) \\
110.5 \\
\end{array}$ & $\begin{array}{c}81.7 \pm 7.6 \\
(69-93) \\
85\end{array}$ & 12.1 & \multicolumn{2}{|c|}{$0.001 * *$} \\
\hline $\begin{array}{l}\begin{array}{l}\text { Post-prandial } \\
\text { glucose }(\mathbf{m g} / \mathbf{d l})\end{array} \\
\end{array}$ & $\begin{array}{c}186.1 \pm 35.6 \\
(158-366) \\
173 \\
\end{array}$ & $\begin{array}{c}135.6 \pm 10.9 \\
(109-164) \\
139 \\
\end{array}$ & 9.4 & \multicolumn{2}{|c|}{$0.001 * *$} \\
\hline Variable & $\begin{array}{c}\text { Case } \\
\text { No(48) } \%\end{array}$ & $\begin{array}{c}\text { Control } \\
\text { No(48) } \%\end{array}$ & $\chi^{2}$ & $\begin{array}{c}\mathrm{p}- \\
\text { value }\end{array}$ & $\begin{array}{c}\text { Odds } \\
\text { (CI 95\%) }\end{array}$ \\
\hline $\begin{array}{l}\text { family history of D.M } \\
\text { No }(45) \\
\text { Yes }(51)\end{array}$ & $\begin{array}{ll}22 & 45.8 \% \\
26 & 54.2 \% \\
\end{array}$ & $\begin{array}{l}47.9 \% \\
52.1 \%\end{array}$ & 0.04 & 0.8 & $\begin{array}{c}0.7 \\
(0.3-6.1)\end{array}$ \\
\hline
\end{tabular}

** Statistically highly significant difference $(\mathrm{P} \leq 0.001) . \quad$ In this table, there was statistically significant elevation in fasting and post-prandial blood glucose levels in the case than the control group. Regarding family history of D.M, there was no statistically significant difference between the two groups. 
ejhm.journals.ekb.eg

Table (5): Comparison between 25(OH) VIT D sufficiency in case and control groups:

\begin{tabular}{|c|c|c|c|c|c|c|}
\hline $25(O H) V I T D$ & & $\%$ & & $\%$ & $\chi^{2}$ & p-value \\
\hline Deficient $<20 \mathrm{ng} / \mathrm{ml}$ & 22 & $45.8 \%$ & 13 & $27.1 \%$ & \multirow{3}{*}{15.6} & \multirow{3}{*}{$0.03 *$} \\
\hline $\begin{array}{l}\text { Insufficient } \\
20-30 \mathrm{ng} / \mathrm{ml}\end{array}$ & 15 & $31.3 \%$ & 16 & $33.3 \%$ & & \\
\hline $\begin{array}{l}\text { Sufficient } \\
>30 \mathrm{ng} / \mathrm{ml}\end{array}$ & 11 & $22.9 \%$ & 19 & $39.6 \%$ & & \\
\hline
\end{tabular}

In this table, there was statistically significant difference between the case and control groups regarding 25 $(\mathrm{OH})$ VIT D sufficiency, with higher percentage of Vit D deficiency in the GDM group.

Figure (1): Bar chart comparing $25(\mathrm{OH}) \mathrm{D}$ sufficiencies between case and control groups

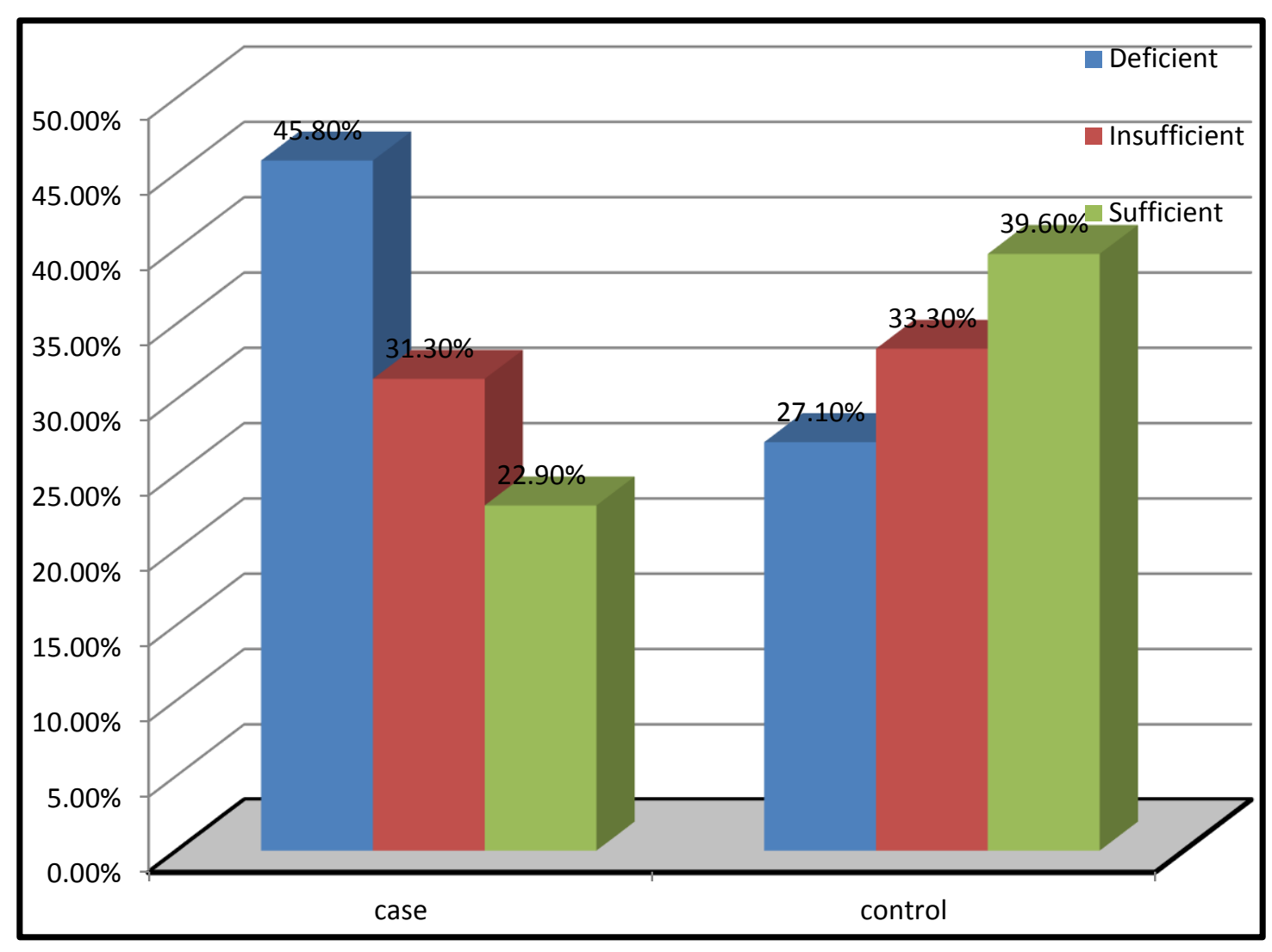


Table (6): Correlation between 25(OH) VIT D and other variables in the gestational diabetes group

\begin{tabular}{|l|lr|}
\hline Variable & $\begin{array}{l}\text { 25(OH) VIT D } \\
\text { r }\end{array}$ & \\
& SIG & \\
\hline BMI & -0.1 & $>0.05$ \\
& NS & $>0.05$ \\
\hline FBG & -0.06 & $>0.05$ \\
& NS & \\
\hline PPBG & -0.03 & $>0.05$ \\
& NS \\
\hline Calcium & 0.02 & \\
& NS & \\
\hline
\end{tabular}

There was negative correlation (insignificant) between Vit $\mathrm{D}$ level and blood glucose level during pregnancy in females with GDM.

\section{DISCUSSION}

About 1 billion people worldwide are found to have Vit D deficiency. In Egypt, Botros et al. ${ }^{(11)}$ found that Vit D deficiency was $72.6 \%$ in nursing group, $54 \%$ in pregnant group, $77.2 \%$ in geriatric group.

The probable mechanisms explaining the relationship between Vit D and GDM are as follows: (1) The direct effect of Vit $D$ on the $\beta$ cells performance. (2) Its effect on intracellular calcium homeostasis, which has a vital role in insulinmediated intracellular processes of insulin-receptor tissue. (3) Effects on systemic inflammation and insulin resistance in T2DM patients ${ }^{(\mathbf{1 2})}$.

In our study, we found that most of the GDM women were deficient in $25(\mathrm{OH}) \mathrm{D}, 45.8 \%$ were $(<20 \mathrm{ng} / \mathrm{ml})$, and about $39.6 \%$ of the control had sufficient $25(\mathrm{OH}) \mathrm{D}(>30 \mathrm{ng} / \mathrm{ml})$ and $33.3 \%$ had insufficient $25(\mathrm{OH}) \mathrm{D}(20-30 \mathrm{ng} / \mathrm{ml})$. This could be explained by that most pregnant females involved in our study belonged to low economic levels which hinder the supplementation of Vit D. Also, they had poor housing circumstances, poor sun exposure, insufficient food intake and lack of medical service. Another vital factor is that, in spite of the sunny weather in Egypt; most of the studied females were veiled, which disable the passage of sunrays to the skin, so decreasing trans-cutaneous Vit D absorption.

This also was found in a study by Aparna et al. ${ }^{(13)}$, where vitamin D deficiency in India was detected in a high incidence in early gestation $(72.8 \%)$ in a tropical country like India despite plentiful sunlight for almost all the year. This paradox could be due to many cultural and social habits e.g. increased urbanization, low outdoor activity, more pollution that hinder sunlight exposure plus absorption of UVB photons by skin melanin, reducing Vit $\mathrm{D}$ synthesis by greater than $90 \%$.

In the current study, the comparison between the two groups showed a statistically significant difference regarding fasting plasma glucose $(\mathrm{mg} / \mathrm{dl})$ and $2 \mathrm{~h}$ postprandial blood glucose during OGTT ( $\mathrm{P}$ value $=0.001)$.

In our study, patients with GDM (case group) had an insignificant negative correlation between maternal serum $25(\mathrm{OH}) \mathrm{D}$ and fasting and post-prandial glucose. Also, there was statistically significant difference between the case and control groups in $25(\mathrm{OH})$ VIT D and calcium levels with higher levels in control group. This is in agreement with Parildar et al. ${ }^{(14)}$ who found that maternal serum levels of $25(\mathrm{OH}) \mathrm{D}$ during pregnancy was significantly less in females with GDM compared to controls.

We found a statistically significant difference between the case and control groups regarding $25(\mathrm{OH})$ VIT D sufficiency, with higher percentage of Vit D deficiency in the GDM group $(45.8 \%$ Vs $27.1 \%)$. This is in agreement with Xia et al. (15) who had a longitudinal study in a multiracial cohort comparing between females with non-deficient levels of Vit D ( $\geq 50 \mathrm{nmol} / \mathrm{L})$ from the $1^{\text {st }}$ to $2^{\text {nd }}$ trimester of gestation and those with persistently deficient Vit D levels $(<50$ $\mathrm{nmol} / \mathrm{L}$ ) who had been significantly at higher risk for developing GDM.

\section{Limitations}

1-Limited number of cases.

2-Inaccurate calculation of sun exposure.

3-Inaccurate records of pre-gestational weight.

4-The effect of some important factors that might affect the relationship between Vit D deficiency and GDM as weight gain during gestation.

This study can be improved by obtaining a larger number of patients. In addition, accurate calculation of pre-gestational weight could better estimate maternal weight gain in gestation and the risk of GDM.

\section{CONCLUSION}

There was an increased prevalence of Vit D insufficiency and deficiency among pregnant females, which may elevate the risk of GDM.

\section{REFERENCES}

1. Farrar D (2016): Hyperglycemia in pregnancy: prevalence, impact, and management challenges. Int J Womens Health, 8: 519-527.

2. Baz B, Riveline JP, Gautier JF (2016): Endocrinology of Pregnancy: gestational diabetes mellitus: definition, aetiological and clinical aspects. Eur J Endocrinol., 174 (2): 43-51. 
3. Bellamy L, Casas JP, Hingorani AD et al. (2009): Type 2 diabetes mellitus after gestational diabetes: a systematic review and meta-analysis. The Lancet, 373 (9677): 1773-9.

4. Rani PR, Begum J (2016): Screening and Diagnosis of Gestational Diabetes Mellitus, Where Do We Stand. J Clin Diagn Res., 10 (4): QE01QE4

5. Erem C, Kuzu UB, Deger O et al. (2015): Prevalence of gestational diabetes mellitus and associated risk factors in Turkish women: the Trabzon GDM Study. Arch Med Sci., 11: 724-73

6. Barrett H, McElduff A (2010): Vitamin D and pregnancy: an old problem revisited," Best Practice and Research. Clinical Endocrinology and Metabolism, 24 (4): 527-529.

7. Wacker M, Holick MF (2013): Sunlight and Vitamin D: A global perspective for health. Dermatoendocrinol., 5 (1): 51-108.

8. Wang H, Chen W, Li D et al. (2017): Vitamin D and Chronic Diseases. Aging and Disease, 8 (3): 346-353.

9. Seshadri K, Tamilselvan B, Rajendran A (2011): Role of Vitamin D in Diabetes. Journal of Endocrinology and Metabolism, 1 (2): 47-56
10. Chagas C, Borges M, Martini L et al. (2012): Focus on Vitamin D, Inflammation and Type 2 Diabetes. Nutrients, 4: 52-67.

11. Botros RM, Sabry IM, Abdelbaky RS et al. (2015): Vitamin D deficiency among healthy Egyptian females. Endocrinol Nutr., 62 (7): 31421.

12.Amraei M, Mohamadpour S, Sayehmiri K et al. (2018): Effects of Vitamin D Deficiency on Incidence Risk of Gestational Diabetes Mellitus: A Systematic Review and Meta-analysis. Front Endocrinol (Lausanne), 9: 7-8.

13 .Aparna $P$, Muthathal S, Nongkynrih B et al. (2018): Vitamin D deficiency in India. J Family Med Prim Care, 7 (2): 324-330.

14.Parildar H, Dogruk Unal A, Aksan Desteli G et al. (2013): Frequency of Vitamin D deficiency in pregnant diabetics at Baskent University Hospital, Istanbul. Pak J Med Sci., 29 (1): 15-20.

15. Xia J, Song Y, Rawal S et al. (2019): Vitamin D Status during Pregnancy and the Risk of Gestational Diabetes Mellitus: A Longitudinal Study in a Multiracial Cohort. Diabetes Obes Metab., 21 (8): 1895-1905. 